\title{
Economics of Marketing of Chickpea in Beed District of Maharashtra
}

\author{
V. S. Chavan*, D. S. Perke and R. D. Shelke \\ Department of Agricultural Economics, Vasantrao Naik Marathwada \\ Krishi Vidyapeeth, Parbhani, India \\ *Corresponding author
}

\section{A B S T R A C T}

\section{Keywords}

Marketing channel, Marketing cost, Margin and price spread

\section{Article Info}

Accepted:

17 October 2020

Available Online:

10 November 2020
The present study was conducted for assess the Economics of Marketing of Chickpea in Beed District of Maharashtra. Chickpea is one of the major pulse crops grown in India. Chickpea is grown in tropical, sub-tropical and temperate regions. Kabuli type is grown in temperate regions while the desi type chickpea is grown in the semi-arid tropics. Markets of chickpea in India are Delhi, Mumbai, Chennai, Hyderabad, Kanpur, Indore, Bikaner and Hapur. The multistage sampling design was used for selection of district, tehsils, villages and chickpea growers. In all 90 chickpea growers were selected to collect the data. The data were collected for the year 2018-19 and analyzed marketing cost, margin and price spread in marketing of chickpea was achieved through tabular analysis. Large quantity of production sold in channel-I (495.2 qt.) followed by channel-II (397.1 qt.) and channel-III (158.2 qt.). The total marketed surplus on chickpea farm was $11.67 \mathrm{q}$, out of which $5.50 \mathrm{q}$, $4.41 \mathrm{q}$ and $1.75 \mathrm{q}$ was marketed thought channel I, II, and III respectively. Total cost of chickpea incurred by village retailer was Rs.97.90 per quintal highest cost incurred by wholesaler was Rs.80.47 in channel-II followed by Rs.75.06 in channel-I. In channel-I price spread was 698.79 followed by 343.11 in channel-II and 41.13 in channel-III.

\section{Introduction}

Chickpea (Cicer arietinum L) is one of the major pulse crops grown in India. Chickpea has the richest, cheapest and easiest source of best quality proteins and fats. Chickpea is important food legumes in many region of the world, particularly in the Indian subcontinents. Domesticated chickpea has been found in Turkey since 3500 BC. Chickpea is grown in tropical, sub-tropical and temperate regions. Its required more than $400 \mathrm{~mm}$ annual rainfall. Kabuli type is grown in temperate regions while the desi type chickpea is grown in the semi-arid tropics. In 2017-18 world production of chickpea was 17.2 million tons, out of which India's production was 577,967 MT. Chickpea occupies 105.73 lakh ha area in 2017-18. In Maharashtra area under chickpea crop was 2000 ' 000 ' ha with production of 1952 ' 000 ' MT and productivity was $816 \mathrm{~kg} / \mathrm{ha}$ during 2017-18. In Maharashtra Amravati, Ahmednagar, Akola, Buldhana, Beed, Dhule, Jalgaon, Latur, Sangli, Solapur are major chickpea growing districts. In Beed district 
the area under chickpea crop was 1245.23 ha with production of 985 ton and productivity $791 \mathrm{~kg} / \mathrm{ha}$ during year 2017-18.

\section{Objective}

To estimate marketing cost, margin and price spread in marketing of chickpea.

\section{Materials and Methods}

The multistage sampling design was used for selection of district, tehsils, villages and chickpea growers. In all 90 chickpea growers were selected to collect the data on production, cost, return, marketing channel, marketing cost, etc. The data were collected for the year 2018-19. In the first stage Beed district was purposely selected for the present study, since it ranks thirteenth in area and production in Maharashtra. In second stage, two tehsils Georai and Majalgaon from Beed district were selected on the basis of maximum area under the chickpea production. In third stage, three villages viz. Chaklamba, Bori-Pimpalgaon and Thakarwadi were selected from Georai tehsil; similarly, Ridhori, Savargaon and Takarwan were selected from Majalgaon tehsil having the highest area under Chickpea production. These all 6 villages were considered for the present study. In the fourth stage 15 chickpea growers were randomly selected from each selected villages. Thus from 6 villages, 90 chickpea growers were selected.

\section{Results and Discussion}

The data collected from the sample farmers were analyzed as per materials and methods.

\section{Major marketing channels in study area}

Major marketing channel are shown in table 1. In the studied area there are three major marketing channel identified which are
Producer-village-retailer-wholesaler-dal processor, $\quad$ Producer-wholesaler-dal processor, Producer-dal processor. Large quantity of production sold in channel-I (495.2 qt.) followed by channel-II (397.1 qt.) and channel-III (158.2 qt.). In channel-I production sold was 47.13 percent, in channel-II production sold was 37.80 percent and in channel-III total production sold was 15.05 percent, respectively. The highest production sold in channel-I followed by channel-II and channel-III, respectively.

Production, retention and marketed surplus of chickpea marketing

Production, retention and marketed surplus of chickpea sold through different channel were calculated and indicated in the table 2 . Production of chickpea 13.22 qt. on 0.837 hector and its retention for seed was 0.87 and for home consumption was 0.68 quintals.

The results revealed that quantity of chickpea as 5.50, 4.41 and 1.75 quintal were marketed through channel-I, channel-II and channel-III, respectively. Thus total marketed surplus of chickpea was 11.67.

\section{Marketing cost of chickpea incurred by different intermediaries}

\section{Marketing cost of chickpea incurred by producer}

Item wise per quintal cost of marketing of chickpea incurred by different channel was presented and calculated in table 3 .

The cost incurred by producer was the highest with Rs.84.71 per quintal in channel-II followed by 48.53 in channel-I and 41.13 per quintal in channel-III.

It was observed that, the proportionate expenditure in the total cost was highest on 
transportation in channel-I (51.51 percent) followed by deduction (42.03 percent). In channel-II share was highest in transportation charges (41.31 percent) followed by commission (21.24 percent) and loading/unloading charges (11.80 percent).

In channel-III share was highest in transportation charges (60.78 percent) followed by loading/unloading charges (24.31 percent), weighing and cleaning charges 14.90 percent.
Marketing cost of chickpea incurred by village retailer

Per quintal marketing cost of chickpea incurred by village retailer was calculated and presented in table 3. Total cost of chickpea incurred by village retailer was Rs.97.90 per quintal. The share of total village retailer charges was highest in commission charges 46.98 percent, followed by transportation charges was 30.64 percent, labour charges 20.42 percent, weighing charges 1.41 percent and shop tax 0.52 percent.

Table.1 Major marketing channel identified in the study area

\begin{tabular}{|c|l|c|c|}
\hline Sr. No & Channels & Total produce sold & Per cent \\
\hline $\mathbf{1}$ & $\begin{array}{l}\text { Channel-I } \\
\text { (Producer - Village retailer - } \\
\text { Wholesaler - Dal processor) }\end{array}$ & 495.2 & 47.13 \\
\hline $\mathbf{2}$ & $\begin{array}{l}\text { Channel-II } \\
\text { (Producer - Wholesaler - Dal } \\
\text { processor) }\end{array}$ & 397.1 & 37.80 \\
\hline $\mathbf{3}$ & $\begin{array}{l}\text { Channel-III } \\
\text { (Producer - Dal processor) }\end{array}$ & 158.2 & 15.05 \\
\hline & Total & $\mathbf{1 0 5 0 . 5}$ & $\mathbf{1 0 0}$ \\
\hline
\end{tabular}

Table.2 Production, retention and marketed surplus of chickpea through different channels

\begin{tabular}{|c|l|c|}
\hline Sr. No & \multicolumn{1}{|c|}{ Particulars } & Chickpea \\
\hline $\mathbf{1}$ & Farm size (ha) & 0.837 \\
\hline $\mathbf{2}$ & Production (qt) & 13.22 \\
\hline $\mathbf{3}$ & Consumption for home & 0.68 \\
\hline $\mathbf{4}$ & Retention for seed & 0.87 \\
\hline $\mathbf{5}$ & $\begin{array}{l}\text { Marketed surplus in channel-I (qt) (Channel-I) - } \\
\text { Producer-village retailer-wholesaler-dal processor }\end{array}$ & 5.50 \\
\hline $\mathbf{6}$ & $\begin{array}{l}\text { Marketed surplus in channel-II (q) (Channel-II) - } \\
\text { Producer-wholesaler-dal processor }\end{array}$ & 4.41 \\
\hline $\mathbf{7}$ & $\begin{array}{l}\text { Marketed surplus in channel -III (q) (Channel-III) } \\
\text { Producer-dal processor }\end{array}$ & 1.75 \\
\hline $\mathbf{8}$ & Quantity sold in the market & 11.67 \\
\hline $\mathbf{9}$ & Total marketed surplus (qt) & 11.67 \\
\hline & & $\mathbf{( 8 8 . 2 7}$ \\
\hline
\end{tabular}


Table.3 Marketing cost of chickpea incurred by different intermediaries

\begin{tabular}{|c|c|c|c|c|}
\hline Sr. No & Particulars & Channel-I & Channel-II & Channel-III \\
\hline & A. Producer & & & \\
\hline \multirow[t]{2}{*}{1} & Loading/Unloading charges & --- & 10 & 10 \\
\hline & & & $(11.80)$ & $(24.31)$ \\
\hline \multirow[t]{2}{*}{2} & Transport charges & 25 & 35 & 25 \\
\hline & & $(51.51)$ & $(41.31)$ & $(60.78)$ \\
\hline \multirow[t]{2}{*}{3} & Weighing and cleaning charges & 3.13 & 6.08 & 6.13 \\
\hline & & $(6.44)$ & $(7.17)$ & $(14.90)$ \\
\hline \multirow[t]{2}{*}{4} & Commission & --- & 18 & --- \\
\hline & & & $(21.24)$ & \\
\hline \multirow[t]{2}{*}{5} & Market fee & --- & 7.09 & --- \\
\hline & & & $(8.36)$ & \\
\hline \multirow[t]{5}{*}{6} & Deduction & 20.40 & 8.54 & --- \\
\hline & & (42.03) & (10.08) & \\
\hline & Sub Total & 48.53 & 84.71 & 41.13 \\
\hline & & (100) & (100) & (100) \\
\hline & B. Village retailer & & & \\
\hline \multirow[t]{2}{*}{1} & Labour charges & 20 & --- & --- \\
\hline & & $(20.42)$ & & \\
\hline \multirow[t]{2}{*}{2} & Transport charges & 30 & --- & --- \\
\hline & & $(30.64)$ & & \\
\hline \multirow[t]{2}{*}{3} & Commission & 46 & --- & --- \\
\hline & & (46.98) & & \\
\hline \multirow[t]{2}{*}{4} & Weighing charges & 1.39 & --- & --- \\
\hline & & $(1.41)$ & & \\
\hline \multirow[t]{5}{*}{5} & Shop tax & 0.51 & --- & --- \\
\hline & & $(0.52)$ & & \\
\hline & Sub Total & 97.90 & --- & --- \\
\hline & & (100) & & \\
\hline & C. Wholesaler & & & \\
\hline \multirow[t]{2}{*}{1} & Labour charges & 10 & 12 & --- \\
\hline & & $(13.32)$ & $(14.91)$ & \\
\hline \multirow[t]{2}{*}{2} & Transport charges & 25 & 30 & --- \\
\hline & & $(33.30)$ & $(37.28)$ & \\
\hline \multirow[t]{2}{*}{3} & License charges & 0.14 & 0.14 & --- \\
\hline & & $(0.18)$ & $(0.17)$ & \\
\hline \multirow[t]{2}{*}{4} & Electronic charges & 0.90 & 0.90 & --- \\
\hline & & (1.19) & $(1.11)$ & \\
\hline \multirow[t]{2}{*}{5} & Market fee & 30 & 28 & --- \\
\hline & & $(39.96)$ & $(34.79)$ & \\
\hline \multirow[t]{2}{*}{6} & Shop tax & 0.44 & 0.43 & --- \\
\hline & & $(0.58)$ & $(0.53)$ & \\
\hline \multirow[t]{5}{*}{7} & Other & 8.58 & 9 & --- \\
\hline & & $(11.43)$ & (11.18) & \\
\hline & Sub Total & 75.06 & 80.47 & --- \\
\hline & & (100) & (100) & \\
\hline & Total & 221.49 & 165.18 & 41.13 \\
\hline
\end{tabular}


Table.4 Per quintal marketing cost, marketing margin and price spread in chickpea crop

\begin{tabular}{|c|c|c|c|c|}
\hline Sr. No & Particulars & Channel-I & Channel-II & Channel-III \\
\hline \multirow[t]{2}{*}{1} & \multirow{2}{*}{$\begin{array}{l}\text { Net price received by Producer (Producers share } \\
\text { in consumer's rupee) }\end{array}$} & 4709.80 & 4874.99 & 5137.63 \\
\hline & & (98.98) & (98.29) & (99.20) \\
\hline \multirow[t]{2}{*}{2} & \multirow[t]{2}{*}{ Expenses incurred by producer } & 48.53 & 84.71 & 41.13 \\
\hline & & $(1.01)$ & $(1.70)$ & $(0.79)$ \\
\hline \multirow[t]{2}{*}{3} & Price paid by village retailer & 4758.33 & --- & --- \\
\hline & & $(90.88)$ & & \\
\hline \multirow[t]{2}{*}{4} & Expenses incurred by village retailer & 97.90 & --- & --- \\
\hline & & $(1.86)$ & & \\
\hline \multirow[t]{2}{*}{5} & Margin of village retailer & 379.30 & --- & --- \\
\hline & & $(7.24)$ & & \\
\hline \multirow[t]{2}{*}{6} & Price paid by wholesaler & 5235.53 & 4959.70 & --- \\
\hline & & $(96.80)$ & $(95.04)$ & \\
\hline \multirow[t]{2}{*}{7} & Expenses incurred by wholesaler & 75.06 & 80.47 & --- \\
\hline & & $(1.38)$ & $(1.54)$ & \\
\hline \multirow[t]{2}{*}{8} & Margin of wholesaler & 98 & 177.93 & --- \\
\hline & & $(1.81)$ & $(3.40)$ & \\
\hline \multirow[t]{2}{*}{9} & Price paid by processor & 5408.59 & 5218.10 & 5178.76 \\
\hline & & $(100)$ & $(100)$ & $(100)$ \\
\hline \multirow[t]{2}{*}{10} & Marketing cost & 221.49 & 165.18 & 41.13 \\
\hline & & (31.69) & (48.17) & $(100)$ \\
\hline \multirow[t]{2}{*}{11} & Marketing margin & 477.30 & 177.93 & --- \\
\hline & & $(68.30)$ & $(51.85)$ & \\
\hline \multirow[t]{2}{*}{12} & Price spread & 698.79 & 343.11 & 41.13 \\
\hline & & (100) & $(100)$ & (100) \\
\hline
\end{tabular}

Marketing cost of chickpea incurred by wholesaler

Per quintal marketing cost of chickpea incurred by wholesaler in channel-I and channel-II was evaluated and presented in table 3. The result revealed that, highest cost incurred by wholesaler was Rs.80.47 in channel-II followed by Rs.75.06 in channel-I. In which share of market fee was highest 39.96 percent in channel-I followed by 34.79 in channel-II. Transportation charges 37.28 percent in channel-II followed by 33.30 percent of transportation charges in channel-I, other charges 11.18 and labour charges 14.91 percent in channel-II.

\section{Price spread in chickpea marketing}

Per quintal marketing cost, marketing margin and price spread in chickpea marketing with respect to different channels was estimated and presented in table 4 . In channel-I price spread was 698.79 followed by 343.11 in channel-II and 41.13 in channel-III. In channel-I village retailer and wholesaler was two intermediaries while in channel-II wholesaler was only one intermediaries. But in channel-III producers are directly selling his produce to dal processor, so dal processor is ultimate consumer, hence it was observed that price spread was Rs.698.79 in channel-I followed by Rs.343.11 in channel-II and Rs.41.13 in channel-III. Thus net price received by producer was Rs.5137.63 in channel-III followed by Rs.4874.99 in channel-II and 4709.80 in channel-I. It is concluded that, the channel-III price spread is lower 41.13 as compared to channel-I and channel-II. That's why it is best channel of marketing as compare to channel-I and channel-I. 
In conclusions

Total cost of chickpea incurred by village retailer was Rs.97.90 per quintal.

Highest cost incurred by wholesaler was Rs.80.47 in channel-II followed by Rs.75.06 in channel-I.

It was cleared that chickpea crop was profitable.

Price spread was more in channel-I i.e. Rs.698.79.

\section{References}

Gajbhiye, S. B. and Kakde, S. J. 2011. Marketing of chickpea in Akola district of Maharashtra. International Journal of Commerce and Business
Management. 4 (2): 228-230.

Govindan, K. L., 2008. Marketing of pulse in Chhindwada district of Madhya Pradesh. Indian J. Agric. Mktg. 54 (9):128-138.

Kumari, M. and Singh, R .2016. Production And Marketing of Chickpea In Bihar: Problems and Prospects For The Farmers. International Journal of Agricultural Science and Research. 6 (3): 125-136.

Pichad, S.P. and Wagh, H.J. 2014. Marketing of chickpea in Amravati district. International Journal of Commerce and Business Management. 7(2): 256259.

Shashikant, V.G., Dubey, L.R., and Kumar, D. (2013). Marketing of Red Gram In Gulbarga District of India. Indian J. Agric. Res.,.47 (5):461-464.

\section{How to cite this article:}

Chavan, V. S., D. S. Perke and Shelke, R. D. 2020. Economics of Marketing of Chickpea in Beed District of Maharashtra. Int.J.Curr.Microbiol.App.Sci. 9(11): 2517-2522.

doi: https://doi.org/10.20546/ijcmas.2020.911.304 